(C) 2021, Emerald Publishing Limited. This AAM is provided for your own personal use only. It may not be used for resale, reprinting, systematic distribution, emailing, or for any other commercial purpose without the permission of the publisher 


\title{
Construction Project Performance: The role of client knowledge and procurement systems
}

\author{
Windapo, A.O ${ }^{1}$, Adediran, A.A ${ }^{2}$, and Rotimi, J.O.B ${ }^{3}$, Umeokafor, N. $^{4}$ \\ ${ }^{1,2}$ Department of Construction Economics and Management, University of Cape Town \\ ${ }^{3}$ School of Built Environment and Engineering, Auckland University of Technology \\ ${ }^{4}$ Department of Civil Engineering, Surveying and Construction Management \\ ${ }^{4}$ Email: nnedinmaik@ hotmail.com
}

\begin{abstract}
Purpose - This study investigates whether clients' knowledge about construction procurement systems influence project performance objectives, and the role of procurement systems on project performance objectives in South Africa.
\end{abstract}

Design/methodology/approach - Using a two-round survey, 90 usable questionnaires from construction professionals in South Africa plus three expert clients were collected. The data were analysed using descriptive statistics - means, percentages and the Analytical Hierarchy Process (AHP) to determine the rank of client project performance criteria, while inferential statistics - Pearson Product Moment Correlation was used in establishing the relationship between level of clients' knowledge and project performance.

Findings - It was found that the common procurement systems used are traditional, followed by management oriented and integrated procurement systems. In addition, it emerged that client's knowledge of procurement systems shows a positive relationship with the achievement of project performance objectives. Based on these findings, it is concluded that some procurement systems being selected by clients in South Africa are inappropriately selected. This is despite the emergence of more efficient procurement systems. If procurement systems are selected based on the knowledge of the client, it will give better chances of successful project outcome.

Practical implications - The research suggests the need for clients to seek ways to improve their understanding or increase their knowledge of procurement systems in construction. Policymakers' responsibilities in driving policies that will place responsibilities on clients to seek a reasonable way to improve their knowledge where possible is implied in the study.

Originality/value - It contributes to improving project performance by examining whether the level of knowledge possessed by a client influences project performance.

Keywords: AHP, Clients, Knowledge, Performance, Procurement, Risk

\section{Introduction}

According to United Nations (2020), many developing countries still lack basic infrastructure such as roads, hence the need for the $9^{\text {th }}$ Sustainable Development Goal 'Build resilient infrastructure, promote sustainable industrialization and foster innovation'. In achieving this goal, there is the need for businesses and projects to meet 
the objectives set. However, despite the efforts to improve productivity, the construction industry is still underperforming in meeting project and business objectives, but some improvements have been made (Chartered Institute of Building (CIOB) 2016; Habibi et al. 2019). While this under-performance is global, developing countries have worse outcomes with countries such as United Arab Emirate seeing half of the projects overrun time (Habibi et al. 2019). Similar underperformance in construction projects is reported in Sri Lanka (Santoso and Gallage 2019). Procurement systems can improve project outcome if used strategically (Eriksson and Westerberg 2011). Mosley and Bubshait (2019) support this. The choice of construction procurement system varies from one project to the other, depending on the amount of information clients have on general operations within the built environment circle, and this could influence project performance either positively or negatively.

Building procurement system can be defined as the combination of construction activities to produce a product (example building or infrastructure). Ratnasabapathy and Rameezdeen (2010) further describe this process, with reference to the client's involvement, where the client sets pre-conditions directed towards the effective attainment of specific project objectives. According to the CIOB (2010), procurement involves the selection of the most suitable organizational structure which will be responsible for the design and construction of the project. Procurement systems used in the construction industry can be broadly characterised as Traditional (Separated and cooperative), Integrated (design and build) and Management Oriented procurement systems (Cooperative Research Centre, 2008; Windapo and Rotimi, 2012).

According to Mosley and Bubshait (2019), building procurement systems have inherent characteristics which allows them to meet certain project performance criteria. The cidb (2014) established that in the South African context, the selection of procurement methods is influential in achieving clients and project objectives. Each procurement system has factors which emphasise on meeting different client and project objectives. The factors within the procurement systems are described by Kamaraswamy and Dissanayaka (2001) as factors which address internal conditions, external conditions, performance criteria and procurement system characteristics. Windapo and Rotimi (2012) and Mathonsi and Thwala (2012) identify these factors as project characteristics, client characteristics and ease of administration.

Akinkunmi, et al. (2018) note that common occurrences of client dissatisfaction coupled with a wide range of procurement systems to select from, results in the construction industry engaging in a bid to seek and select a more efficient approach to procurement systems in order to better the performance criteria on building projects. Mathonsi and Thwala (2012) further identifies the difficulties encountered in the industry with regards to the need and selection of alternative procurement systems. Mason (2016) notes that the emergence of new procurement systems has led to a shift from traditional methods to more efficient integrated systems which enables better project time, quality and risk performances.

However, while there are a lot of factors (including project characteristics, client objectives and characteristics) that determine the selection of appropriate system, client knowledge of the procurement systems (one of the characteristics of clients) is 
fundamental in its selection. Rwelamila and Meyer (1999) found that there is little knowledge of the different procurement systems and their variations and that procurement systems are selected inappropriately. This lack of knowledge may be applicable to clients and members of the project team. Similarly, Warsame (2013:8) found that 'Without knowledge and the right incentives, it is unlikely that any procurement type will lead to high quality results and an organization with the right knowledge and incentives can adjust any procurement type to the situation and make it work'. The knowledge enables clients to consider the factors within the different available procurement systems in order to select the most appropriate system to meet client and project performance objectives. This knowledge is informed by the client's level of experience in the construction industry which Mathonsi and Thwala (2012) report as an important factor in the selection of the appropriate procurement strategy.

In South Africa, a country that is primarily focused on using traditional procurement systems (Mbanjwa and Basson 2003), the Construction Industry Development Board Construction (cidb) Industry Indicators (CIIs) show client dissatisfaction with regard to quality of the works delivered, condition of facility at handover, resolution of defective work during the construction period by the main contractor and overall quality of materials used (cidb, 2011). It has therefore become less viable to make use of traditional procurement systems and despite the emergence of a variety of new and more efficient procurement systems, there is inappropriateness in the procurement systems being selected by clients.

Despite the background established so far, there are still grey areas in some aspects of procurement in the South African construction industry. Typically, there is the need to add to the body of knowledge on whether clients consider the factors within the different available procurement systems in selecting the most appropriate one to meet their objectives and project performance objectives. The extant studies such as Mathonsi and Thwala (2012) and Thwala and Mathonsi (2012) have limitations. For example, they have not examined the client knowledge of procurement in detail like the current study does. Mathonsi and Thwala (2012) adopted a Delphi (where 21 respondents) were used. While the method is developed and widely used in many studies, it has been criticised for its limitations, just like other research methodologies. The limitations are not limited to researcher bias, there is the risk that the researcher will impose his/her preconceptions on the respondents (Avella 2016). This does not mean that the findings in the extant studies should be disregarded, rather there is the need for more studies on the topic using another methodology. The current study intends to fill this gap in knowledge by examining the procurement system frequently used on construction projects in South Africa and whether the clients' knowledge of project procurement systems is related to project performance objectives. It is expected that the study will contribute to the existing efforts to improving project performance by demonstrating or advancing the understanding and implications of client knowledge of procurement for project delivery. The implications of the findings are not limited to responsibilities for policymakers to drive policies that enable the enforcement of client obligation to seek a reasonable way to improve their knowledge of procurement.

The study proposes that the client's knowledge of procurement system is a key factor within procurement systems that impacts on the project performance. To conduct the 
study and test this proposition, the research first of all undertakes an analytical review of extant literature pertaining to construction procurement systems and factors within the system that impacts on project performance. Thereafter, it collects empirical data through a quantitative research approach that includes experts and questionnaires, and finally, it provides conclusions and recommendations that address the problems of the study.

\section{Procurement systems}

This section presents a review of the main procurement systems used in the construction industry, the client project performance criteria and factors within procurement systems that affect project performance objectives. Finally, it presents a theoretical framework that details the elements and relationships to be investigated in the research.

\section{Overview of procurement systems}

Procurement systems used in the industry can be broadly characterised as Traditional (Separated and cooperative), Integrated (design and build) and Management Oriented procurement systems. In addition, there is a wide range of procurement strategies which are sub-classifications of the above-mentioned systems as shown in Table 1.

Table 1. Sub-classification of building procurement systems

\begin{tabular}{|c|c|c|}
\hline Traditional Procurement & Integrated Procurement & Management oriented \\
\hline $\begin{array}{ll}\text { - } & \text { Lump sum } \\
\text { - } & \text { Provisional Quantities } \\
& \text { (Measurement contracts) } \\
\text { - } & \text { Cost reimbursement }\end{array}$ & $\begin{array}{ll}\text { - } & \text { Design and build } \\
\text { - } & \text { Build Operate and transfer } \\
\text { - } & \text { Public private partnership } \\
\text { - } & \text { Private finance initiative } \\
\text { - } & \text { Package deal/turnkey }\end{array}$ & $\begin{array}{ll}\text { - } & \text { Management } \\
& \text { contracting } \\
\text { - } & \text { Design and manage } \\
\text { - } & \text { Construction } \\
& \text { management } \\
\text { - } & \text { Labour only contracting }\end{array}$ \\
\hline
\end{tabular}

Adapted from Love et al. (1998); Alhazmi and McCaffer (2000); Cooperative Research Centre (2008); Windapo and Rotimi (2012).

\section{Traditional procurement systems}

The traditional method of procurement has been in existence and was the only procurement system available to clients for many years and is the system which is best understood by clients (Cooperative Research Centre, 2008; CIOB, 2010). Notably the traditional system has classifications that separate the functions of design and construction (Windapo and Rotimi, 2012; Hughes et al., 2015). Two separate organisations enter into different contracts with the client (Mason 2016). The design teams prepare the contract documentation and advise the client on the actions to be undertaken in order to fulfil the client's requirements. Parallel to advising the client, the design work is carried out with an objective to model a solution which will meet the client's requirements (Mathonsi and Thwala, 2012). The variants of the traditional procurement system are the lump sum, provisional quantities and cost reimbursement. 


\section{Integrated Procurement Systems}

In Integrated procurement systems, the project design and execution phases are handled by one organisation which takes responsibility for both aspects of project procurement. The client can therefore enter into one agreement with an organisation which will facilitate the project delivery process. The underlying concept is that one organisation will be responsible for the project in terms of outlining client requirements, design and construction. The main contractor responsible for the project can have different contracting teams involved in the project (Lam et al., 2003). There are a number of variant strategies that can be defined under the integrated procurement system. The range of variants include, design and build, build, operate and transfer, public private partnership, private finance initiative and package deal or turnkey procurement. Each of these systems facilitate the project delivery process in a cohesive manner by integrating the design and construction phase (Thwala and Mathonsi, 2012).

\section{Management Orientated}

Management oriented procurement systems have a structure in which the project would be managed by a project or construction manager. The construction manager works with the design team and other consultants in producing designs and the team also manages the physical work carried out on site by the contractors (Mathonsi and Thwala, 2012). The Cooperative Research Centre (2008) mentions that there are several forms of management procurement systems which include management contracting, construction management and design and manage. In management contracting, the main contractor has direct contractual links with all the sub-contractors and is in charge of all the works on site. In a construction management approach, the main contractor is hired to manage, prepare a construction programme and facilitate the process between design and construction. The main contractor is there to simplify the relationship between the design team and the construction team, thus enabling a better outcome in terms of the project objectives and communication (Cooperative Research Centre, 2008).

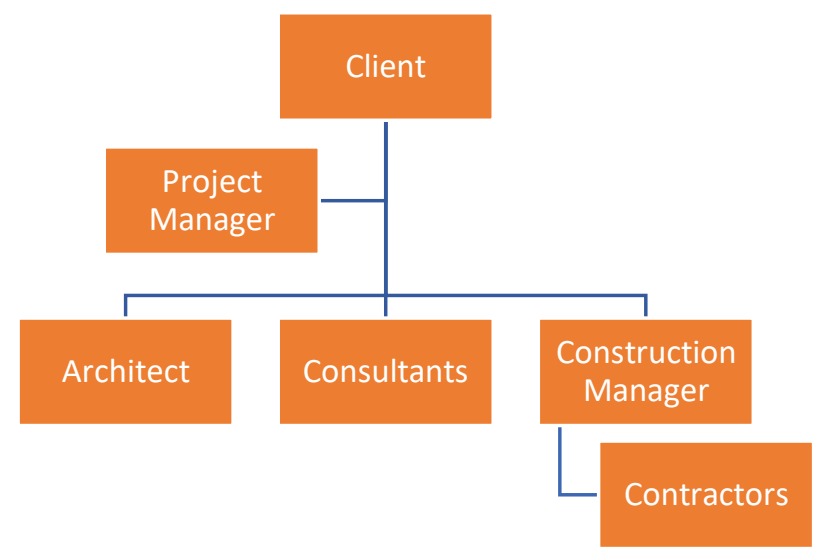

Figure 1:Construction Management Procurement (Adapted from the Cooperative Research Centre, 2008) 


\section{Commonly used procurement systems in South Africa}

Procurement systems used in South Africa are derived from British Models (Mathonsi and Thwala, 2012). Grobler and Pretorius (2002) and, Mbanjwa and Basson (2003) found that traditional procurement is more often adopted in Southern Africa followed by management oriented and integrated systems. These studies reflect that traditional procurement system is the preferred and widely used procurement method in South Africa. Mathonsi and Thwala (2012) establish that the history of South Africa and its socio-political factors play a role in the types of procurement systems adopted in the industry, however, it is observed that public clients focus more on such external factors than private clients do.

Conversely, in a review of 16 studies (from 1996 - 2013) in various countries across different projects including highways and construction, Mosley and Bushait (2019) indicate that design and build performs better than traditional procurement methods based on project performance indicators including time, cost, productivity, growth rate and change order. However, while the number of the procurement methods (e.g. traditional and design and build only or more) examined in the studies were omitted (which would have implications for the outcome), Mosley and Bushait (2019) acknowledge the discord among scholars on the discourse, demonstrating (in line with Ibss et al. 2003) that none of the two out-performs the other as they are influenced by the level of experience and expertise of those administering them. Besides, the implications of the missing information in Mosley and Bushait (2019), include that the findings may be biased and interpretation of the results by the readers limited.

\section{Client project performance criteria}

According to $\mathrm{Ng}$ et al. (2002) and Umeokafor (2018), there is always an expectation that time cost and quality would be considered as project performance criteria and in literature these criteria are cited more often than others. The client project performance criteria are presented in Table 2 .

Table 2. Client performance criteria

\begin{tabular}{|l|l|l|}
\hline $\begin{array}{l}\text { Performance } \\
\text { Measures }\end{array}$ & Criteria & Citing Authors \\
\hline Cost & $\begin{array}{l}\text { The cost target or budget set } \\
\text { by the client }\end{array}$ & $\begin{array}{l}\text { Ward et al. (1991); Kumaraswamy and } \\
\text { Dissanayaka (1998); Love } \text { et al. (1998); Brown } \\
\text { and Adams (2000); Kamara } \text { et al., (2002); Chan et } \\
\text { al. (2002); Chan and Chan (2004); Umeokafor } \\
\text { (2018); Mosley and Bushait (2019). }\end{array}$ \\
\hline Time & $\begin{array}{l}\text { The time frame to complete } \\
\text { the project } \\
\text { Dissanayaka (1998); Love et al. (1998); Kamara } \\
\text { et al. (2002); Chan } \text { et al. (2002); Chan and Chan } \\
\text { (2004); Umeokafor (2018) }\end{array}$ \\
\hline Quality & $\begin{array}{l}\text { Ward et al. (1991); Love et al. (1998); } \\
\text { Kumaraswamy and Dissanayaka (1998); Chan } \text { et } \\
\text { al. (2002); Chan and Chan (2004); Umeokafor } \\
\text { (2018); Mosley and Bushait (2019). }\end{array}$ \\
\hline
\end{tabular}




\begin{tabular}{|l|l|l|}
\hline Health and Safety & $\begin{array}{l}\text { The prevention and avoidance } \\
\text { of incidents and accidents }\end{array}$ & $\begin{array}{l}\text { Kumaraswamy and Dissanayaka (1998); Chan } \text { et } \\
\text { al. (2002); Chan and Chan (2004); Umeokafor } \\
(2018) ; \text { Mosley and Bushait (2019) }\end{array}$ \\
\hline Aesthetics & The design of the project & $\begin{array}{l}\text { Kumaraswamy and Dissanayaka (1998); Kamara } \\
\text { et al. (2002) }\end{array}$ \\
\hline $\begin{array}{l}\text { Environmental } \\
\text { Considerations }\end{array}$ & $\begin{array}{l}\text { The impact of the building on } \\
\text { the environment }\end{array}$ & $\begin{array}{l}\text { Kumaraswamy and Dissanayaka (1998); Chan } \text { et } \\
\text { al. (2002); Kamara } \text { et al. (2002); Chan and Chan } \\
\text { (2004); Chen } \text { et al. (2010) }\end{array}$ \\
\hline Sustainability & $\begin{array}{l}\text { Impact on design on natural } \\
\text { resources }\end{array}$ & $\begin{array}{l}\text { Kamara } \text { et al. (2002); Chan } \text { et al. (2002); Ugwu } \\
\text { and Haupt (2007); Chen } \text { et al. (2010) }\end{array}$ \\
\hline $\begin{array}{l}\text { Technical } \\
\text { performance }\end{array}$ & $\begin{array}{l}\text { Outcome of project compared } \\
\text { to technical requirements }\end{array}$ & Chan et al. (2002) \\
\hline
\end{tabular}

The priority of the project performance criteria - cost, time, quality, health and safety, and environmental considerations, which represents client needs, differs depending on the perspectives of the client. Therefore, this study posits that an understanding of the project performance criteria which are prioritised by clients, assists clients in developing a method of selecting best fitting procurement systems for their projects.

\section{Factors within procurement systems that impact on project performance}

Studies by Windapo and Rotimi (2012) and Habibi et al. (2019) suggest that there is a relationship between project success and the procurement system chosen for the delivery of the project. According to the Cooperative Research Centre (2008) and Mason (2016) each type of procurement system has its strengths and weaknesses depending on its inherent characteristics, making some procurement systems better suited to a set of performance objectives than others. Thwala and Mathonsi (2012) found that the factors which would influence the selection of the applicable procurement, are factors which touch on all stages of the project.

In several studies (e.g. Mbachu and Nkado, 2006; Cooperative Research Centre, 2008; and Thwala and Mathonsi, 2012), a number of factors which can be applicable to various types of procurement systems are identified as impacting on project performance; these factors consist of - clients level of knowledge (represents the client's level of knowledge and their ability to communicate their needs); client's level of control (the responsibility which the client assumes on the project); risk allocation (gives an indication of how much risk and whether the risk has been fairly assigned to the contractor and other parties in the project organisation); accelerated project delivery (the need for a project to be completed in a shorter duration than another project of an identical nature, technical complexity and size); technical complexity of the project (translates into the client's need for the project to be highly specialized and technologically advanced; political considerations (external and uncontrollable environmental factors which host issues relating to empowerment, business controls, fiscal policies, taxes, statutory regulations, which influences the client and the client's business during the project); and social consideration (socio-political or socio-cultural factors such as cultural influences, social stigma, gangsterism, workers' morale to work, health and labour union demands, which can affect the internal environment of the project). This study investigates whether the knowledge of clients of procurement systems can be related to project performance. 


\section{Analytical and conceptual framework of the study}

The impact of the client's knowledge and their ability to communicate their needs on project performance, within the three identified procurement systems used on construction projects are further investigated in this study. The conceptual framework upon which this study is adapted is from studies by Kumaraswamy and Dissanayaka (1998), The Cooperative Research Centre (2008), Mfongeh (2010) and Mathonsi and Thwala (2012). The conceptual framework of the relationship between the client's knowledge as a factor within procurement systems that influences project performance is shown in Figure 2.

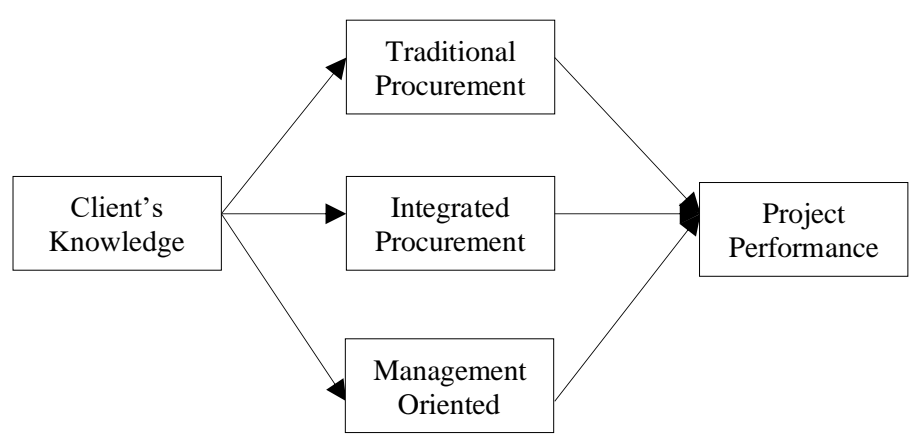

Figure 2: Conceptual Model showing the influence of Client's knowledge of procurement systems on project performance (Adapted from Kumaraswamy and Dissanayaka, 1998; Bowen et al., 1999; The Cooperative Research Centre, 2008; Mfongeh, 2010; and Mathonsi and Thwala, 2012).

The experience of the client represents their level of knowledge and their ability to communicate their needs which play an important role in identifying the requirements for the project. In the framework developed by Kumaraswamy and Dissanayaka (1998), the client's level of experience is a factor which can assist in structuring the appropriate procurement system. The client's knowledge is categorized under contextual conditions which can weigh up on the project and understanding the factor beforehand can be used to build a project profile (Kumaraswamy and Dissanayaka, 1998; Mathonsi and Thwala, 2012). The Cooperative Research Centre (2008), Mfongeh, (2010) and Mathonsi and Thwala (2012) established that the client's level of experience in the construction industry is an important factor in selecting the appropriate procurement strategy. The client needs an appropriate level of experience to interact with professionals during the project delivery process and to know exactly what he wants and what his requirements are (Mfongeh, 2010).

Previous research by Kumaraswamy and Dissanayaka, (1998), further supported by Mathonsi and Thwala (2012) and Borg (2015) show that the client's level of experience/knowledge has an impact on most of the sub-systems of a procurement system. It is however not known whether the level of experience/knowledge possessed 
by a client influences project performance (see Figure 2). This study therefore hypothesizes as follows:

$\mathrm{H}_{1}$ : The level of experience/knowledge possessed by a client within a procurement system has a direct relationship with the level of project performance.

\section{Research Methodology}

Using two rounds of data collection, the study employed a quantitative research approach involving a questionnaire survey in collecting empirical data from a sample of expert clients, expert client representatives and experienced construction professionals including architects, quantity surveyors, construction managers, project managers and engineers. Typically, round 1, consists of providing structured questions to client representatives in the construction industry. Hence, a convenience sampling technique was used in identifying participants (experts) who have experience with construction project procurement. Round 2, consists of a survey to establish project performance and factors contributing to the level of project performance including client knowledge and procurement systems used. Therefore, a random sampling technique was used in identifying participants from a Register of Professionals and Projects (Times Media (2015) Professionals and Project Register in South Africa).

The objectives of the study required a population knowledgeable in the outcomes of procurement systems used on construction projects. The sample size of the study consisted of 693 quantity surveyors, construction managers, project managers, architects and engineers randomly selected from a population of 2563 construction professionals listed in the Professions and Projects Register (2015) in South Africa. At the end of the first round (survey questionnaire), 121 responses were obtained which translates into a $17.5 \%$ response rate but 90 were usable. While the usable ones account for about $13 \%$ response rate, studies such as Dulami et al. (2003) are based on response rate as low as $5.91 \%$. Although the result may be influenced with sample bias because of the low response rate (Dulami et al. 2003), Coviello and Jones (2004: 494) state that 'if highquality survey data are obtainable from a smaller sample drawn using well-developed selection criteria, meaningful findings can still result'.

The second round (Analytical Hierarchy Process (AHP)), was completed by three respondents. AHP requires that experts who are representative of the problem being examined are used. It is a technique that provides a comparison rating of substitutes to give an indication of appropriate alternatives on which to focus. It is used to establish the weights assigned to different criteria (in this study that is project performance attributes) by the decision maker/expert. In particular, in this study, it is the construction project performance criteria which are then used to calculate a performance score for the projects identified by each respondent in the general survey.

In a further elaboration by Saaty (1994), the AHP is recognised to be based on the philosophy that, individual knowledge about a criterion is not sufficient in making decisions which concern a group. For instance, if success is determined by achieving a certain level of performance for a number of criteria, a decision about success cannot be made by assessing only one criterion (Oladapo, 2011). According to Oladapo (2011) the set of elements or criteria is considered in order to provide the judgement on the importance of these activities and to quantify the judgements. 
AHP is a flexible and adaptable tool and it has therefore found several applications in the field of engineering and the built environment. For instance, it has been used by Alhazmi and McCaffer (2000) in procurement selection methodology as well as success factors for different project objectives (Chua et al., 1999), or to contractor selection methods (Oladapo, 2011) and building components (Moghayedi and Windapo, 2018). According to Pomponi et al. (2019) the AHP can be divided into the following steps:

1. Structure the decision hierarchy, considering the goal of the study and determining the criteria and sub-criteria

2. Establish a set of all judgements in the comparison matrix in which the set of elements is compared to itself;

3. Determine the relative importance of factors by calculating the corresponding eigenvectors to the maximum eigenvalues of comparison;

4. Verify the consistency of judgements across the Consistency Index (CI) and the Consistency Ratio (CR).

According to Doloi (2008), the major advantage of AHP is that it does not always require statistically significant sample size to achieve sound and statistically robust results. That is, a small sample size is not an issue from the AHP methodology, and the response of a single qualified expert is usually representative (Abudayyeh et al., 2007). AHP has been used with small groups by Oladapo (2011) and Pomponi et al. (2019). AHP provides a comparative rating of substitutes and gives an indication of appropriate alternatives in which to focus.

Unlike other decision-making methods which attempt to determine the relative importance, or weight, of alternatives in terms of each criterion involved in a given decision-making problem, AHP (as proposed by Saaty,1990) requires the decision maker to express his/her opinion about the value of one single pair-wise comparison at a time using what Saaty (2001) calls a fundamental scale. The fundamental scale is a one-to-one mapping between the set of discrete linguistic choices available to the decision maker and a discrete set of numbers which quantify the linguistic choices. Many scales exist but the most popular is the one proposed by Saaty (2001) and shown in Table 3.

Table 3: Fundamental Scale

\begin{tabular}{|c|l|l|}
\hline $\begin{array}{c}\text { Intensity of } \\
\text { importance }\end{array}$ & \multicolumn{1}{|c|}{ Definition } & \multicolumn{1}{c|}{ Explanation } \\
\hline 1 & Equal importance & $\begin{array}{l}\text { Two activities contribute equally to } \\
\text { the objective }\end{array}$ \\
\hline 2 & Weak & Between equal and moderate \\
\hline 3 & Moderate importance & $\begin{array}{l}\text { Experience and judgment slightly } \\
\text { favour one activity over another }\end{array}$ \\
\hline 4 & Moderate plus & Between strong and very strong \\
\hline 5 & Strong importance & $\begin{array}{l}\text { Experience and judgment strongly } \\
\text { favour one activity over another }\end{array}$ \\
\hline 6 & Strong plus & Between strong and very strong \\
\hline
\end{tabular}




\begin{tabular}{|c|l|l|}
\hline 7 & $\begin{array}{l}\text { Very strong or demonstrated } \\
\text { importance }\end{array}$ & $\begin{array}{l}\text { An activity is favoured very strongly } \\
\text { over another; its dominance } \\
\text { demonstrated in practice }\end{array}$ \\
\hline 8 & Very, very strong & Between very strong and extreme \\
\hline 9 & Extreme importance & $\begin{array}{l}\text { The evidence favouring one activity } \\
\text { over another is of the highest possible } \\
\text { order of affirmation }\end{array}$ \\
$\begin{array}{c}\text { Reciprocals } \\
\text { of above }\end{array}$ & $\begin{array}{l}\text { If activity I has one of the } \\
\text { above numbers, when } \\
\text { compared with activity } j, \text { then } j \\
\text { has the reciprocal value when } \\
\text { compared with } i .\end{array}$ & If $\mathrm{x}$ is 5 times $\mathrm{y}$, then $\mathrm{y}=1 / 5 \mathrm{x}$ \\
\hline
\end{tabular}

Source: Saaty (2001)

A pairwise comparison is employed, through the assistance of experts or decision makers who compare the criteria forming the questionnaire. These components form a matrix which corresponds to the number of elements compared (Vaidya and Kumar, 2006). From the matrix, a range of computations are performed to determine, in numerical terms, the importance of each of the criteria. Processed numerical values will be used to determine the ranking of each alternative being compared (Oladapo, 2011). CGI (AHP) software is used to calculate the weights of the comparison matrices and the consistency index.

A couple of values resulting from the computations conducted have to be noted, Eigenvector and Eigenvalue (Consistency Index). These computations are done to determine, the priority of weighting and the consistency of the decision makers. Computer software can be employed to compute the values as mentioned above (Vaidya and Kumar, 2004). In Saaty's (1994) study, the acceptable consistency ratio values are given as 0.05 for a $3 \times 3$ matrix, 0.08 for a $4 \times 4$ matrix and 0.1 for larger matrices. The weights determined from the computations are used for decision making and choice of the different given scenarios.

This study made use of Pearson product correlation analysis to determine the strength and direction (positive or negative) of a linear relationship between project performance and factors hypothesized in literature that impact project performance. A positive correlation means that as the magnitude of one variable increases, the other variable will increase as well. A negative correlation means that as one variable increases, the other variable will decrease (Pallant, 2010). The Pearson correlation coefficient can take any value between $-1$

The questionnaire survey gathered information pertaining to the professionals' knowledge of the range of available procurement systems and the performance of projects on which they were used. Identifying the respective professions responding to the procurement related questions was also essential as it validates the level of their involvement in construction project procurement. The questionnaire was thus designed to have two sections. Section A was designed for the collection of demographic data. Also, using an ordinary linear likert scale (from very poor (1) to very good (5)), the respondents level of awareness of each of the three procurement systems, traditional, integrated and management oriented, were assessed. To conform to the study, the respondents should be 
knowledgeable of the construction industry and should also have a good knowledge of the project procurement systems they have been involved with. Section B comprised of the professionals' knowledge and experience with project procurement systems. This included closed questions relating to the type of project procurement information and level of performance. The first round consists of administering the questionnaire to expert client representatives in the construction industry to determine the important client objectives and their respective weights, based on a range of common criteria made available in the questionnaire. Consultants such as architects, client quantity surveyors and engineers also work as client representatives and are able to provide information about the client. Studies such as Umeokafor (2017, 2018) and Alinaitwe (2008) have surveyed consultants such as the aforementioned to collect data about clients.

In the second round, questionnaires were distributed via Surveymonkey.com to evaluate the level of the client's knowledge of procurement and project performance. The respondents were asked to rate the performance of the identified project according to the client objectives of time, cost, quality, $\mathrm{H} \& \mathrm{~S}$, sustainability and environmental considerations. The objectives were each assigned a rating on a scale of " 1 " to " $10 "$ ". " 1 " being "very poor" and "10" being "excellent". Additionally, ordinary linear likert scale (from very poor (1) to very good (5)), the respondents' level of awareness of each of the three procurement systems, traditional, integrated and management oriented, were assessed

The data obtained from the survey were analysed using descriptive statistics - means, percentages and the AHP, and inferential statistics - the Pearson Product correlation test, $\rho$. AHP is a process and the steps therein can be used to determine if it is the best fit for ranking the process/problem. A pairwise comparison is employed, through the assistance of experts or decision makers who compare the criteria - project performance, forming the question. These components form a matrix which corresponds to the number of elements compared (Chen et al., 2010; Vaidya and Kumar, 2006). From the matrix, a range of computations are performed to determine, in numerical terms, the importance of each of the criteria. Processed numerical values are used to determine the ranking of each alternative being compared (Oladapo, 2011). CGI (AHP) Software is used to calculate the weights of the comparison matrices and consistency index. Correlation analysis was used to determine the strength and direction (positive or negative) of a linear relationship between the level of client knowledge and project performance index (PPI). A positive correlation means that as the value of one variable increases, the other variable will increase as well. A negative correlation means that as one variable increases, the other variable will decrease (Pallant, 2010).

\section{Findings and Discussion}

In this section, the empirical data collected through the questionnaire survey are presented, analysed and discussed.

\section{Demographics of Survey Respondents}

The data obtained in the questionnaire survey indicated that $24(27 \%)$ of the respondents were Quantity Surveyors and another 24 (27\%) were construction managers, 10 (11\%), $12(13 \%), 8(9 \%)$ were project managers, engineers and architects respectively. A further $12(13 \%)$ were other professionals such as health and safety managers working in the 
construction industry. The data collected also shows that $57(63 \%)$ of the respondents have more than 21 years of experience and $70(78 \%)$ have worked on more than 21 projects in the construction industry. These results suggest that the respondents must have been fully exposed to different construction experiences, knowledge and projects and could therefore provide valuable information relevant for this study.

\section{Analytic Hierarchy Process (AHP)}

The AHP questionnaire used for ranking the client performance factors was completed by 3 clients - 2 Quantity Surveyors working in the private sector as client representatives and a construction manager working in the private sector. Pairwise comparisons included client performance criteria established in literature review. These included time, cost, quality, health and safety, environmental considerations and sustainability as shown in Table 4. The responses obtained in the pairwise comparisons were used as inputs to determine the ranking of the performance criteria by each respondent.

Table 4. Matrix for Average Aggregate Scores

\begin{tabular}{|l|l|l|l|l|l|l|l|}
\hline $\begin{array}{l}\text { Client } \\
\text { Performance } \\
\text { Criteria }\end{array}$ & Time & Cost & Quality & H\&S & Sustainability & $\begin{array}{l}\text { Environmental } \\
\text { Considerations }\end{array}$ & Weight \\
\hline Time & 1.000 & 0.667 & 4.000 & 2.733 & 2.667 & 3.333 & 0.281 \\
\hline Cost & 1.500 & 1.000 & 3.667 & 3.000 & 3.333 & 4.000 & 0.329 \\
\hline Quality & 0.250 & 0.273 & 1.000 & 3.333 & 3.000 & 3.333 & 0.164 \\
\hline H\&S & 0.366 & 0.333 & 0.300 & 1.000 & 1.111 & 2.000 & 0.086 \\
\hline Sustainability & 0.375 & 0.300 & 0.333 & 0.900 & 1.000 & 2.333 & 0.086 \\
\hline $\begin{array}{l}\text { Environmental } \\
\text { Considerations }\end{array}$ & 0.300 & 0.250 & 0.300 & 0.500 & 0.429 & 1.000 & 0.055 \\
\hline
\end{tabular}

Key: H\&S = Health and Safety

All the respondents' pairwise comparisons of the criteria were averaged and a mean score was developed for each. Table 4 shows the matrix developed for all the three respondents in order to calculate the weights of the criteria. From Table 4, it can be deduced that merging the results from all respondents respectively gives the clients performance criteria weighting in the following order: cost, time, quality, $H \& S$ and sustainability ranked equally and finally environmental considerations. The order outlined by the rank of the client performance criteria is understood to be the order as perceived by expert client representatives to be important for client satisfaction. To satisfy the clients, the projects should achieve the performance objectives specifically in the order of preference of the client as shown by the weighting.

\section{Projects studied and level of performance}

The respondents were asked to consider a particular project with which they are familiar so that they would be in a particular mind frame when answering the questions that followed. This instruction was expected to yield a higher degree of accuracy and cohesion in the responses provided. Based on this enquiry, it was found that $70 \%$ of the projects identified by the respondents were procured using the traditional procurement system, followed by management oriented (18\%) and integrated procurement systems (12\%). It was also found that $65.5 \%$ were public sector projects while $34.5 \%$ were private sector projects. Table 5 gives a detailed breakdown of the responses collected in the survey, 
categorised according to the particular procurement strategy used for the projects and a weighted mean average that indicates how each of the client's objectives performed in the different procurement systems and overall in the Project Performance Index (PPI).

Table 5 suggests that overall, in terms of total aggregate performance levels, the integrated procurement method was perceived to provide clients with the best project outcomes, followed by the management oriented and lastly, by the traditional method of procurement. In terms of client criteria, it was found that the Integrated methods of procurement achieved the best overall outcome in five key areas of time, cost, quality, sustainability and environmental considerations.

Table 5. Average PPI Scores based on Client Criteria distributed by Procurement Methods

\begin{tabular}{|l|l|l|l|l|l|l|l|}
\hline $\begin{array}{l}\text { Procurement } \\
\text { Method }\end{array}$ & Time & Cost & Quality & H\&S & Sustainability & $\begin{array}{l}\text { Environmental } \\
\text { Considerations }\end{array}$ & PPI \\
\hline (AHP Weights) & 0.281 & 0.329 & 0.164 & 0.086 & 0.086 & 0.055 & \\
\hline Traditional & 6.94 & 7.37 & 7.71 & 7.73 & 7.33 & 6.94 & 7.314 \\
\hline Integrated & 7.73 & 8.00 & 8.55 & 8.36 & 8.64 & 8.18 & 8.117 \\
\hline $\begin{array}{l}\text { Management } \\
\text { Oriented }\end{array}$ & 7.56 & 7.31 & 8.25 & 8.44 & 8.06 & 7.81 & 7.733 \\
\hline Average Scores & 7.41 & 7.56 & 8.17 & 8.18 & 8.01 & 7.64 & \\
\hline
\end{tabular}

\section{Relationship between the Level of Client's Knowledge and Project Performance}

The study sought to know whether the level of the client's knowledge and experience of procurement systems is related to project performance measured using the Project Performance Index (PPI). The level of the client's knowledge and experience of project procurement systems were plotted against their corresponding PPI according to the procurement methods used. The relationship between the client's knowledge and experience of procurement system obtained per case and the PPI of that particular project is illustrated in Figures 3 to Figure 5, while the test of correlation of the relationship between client's knowledge and PPI is presented in Table 6.

Table 6. Pearson Relationship between PPI and Client Knowledge distributed by Procurement Methods

\begin{tabular}{|l|l|l|l|l|}
\hline Variable & R calculated & d.f. & R tabulated & Significance \\
\hline Traditional Procurement & $0.366^{* *}$ & 60 & 0.325 & 0.01 \\
\hline Integrated Procurement & $0.872^{* * *}$ & 9 & 0.872 & 0.001 \\
\hline Management Oriented System & $0.535^{*}$ & 14 & 0.514 & 0.05 \\
\hline
\end{tabular}

Table 6 shows that the knowledge of the client as a procurement system factor is significantly and positively related to project performance. However, it has a more significant level of relationship in the integrated procurement system followed by the traditional procurement and the management-oriented procurement system. Further interrogation of the data collected (see Figures 3-5) also show a positive relationship between the knowledge of the client and project performance within the different procurement systems. The slope of the trend line suggests that the more the client's level 
of knowledge of the procurement system, the higher the project performance. Figure 4 also shows that $77 \%$ of the change in the project performance within projects procured through the integrated methods of procurement is determined by changes in the Client's knowledge levels.

\section{Discussion of Findings}

The survey findings suggest that cost is the highest weighted construction project performance criteria, followed by time and quality; that the traditional procurement system is frequently used on projects in South Africa; that integrated procurement system provide clients with the best overall project outcomes; and that there is a significant positive relationship between the client's level of knowledge and project performance within the different procurement systems. However, the integrated procurement system shows the best fit between client's level of knowledge and project performance.

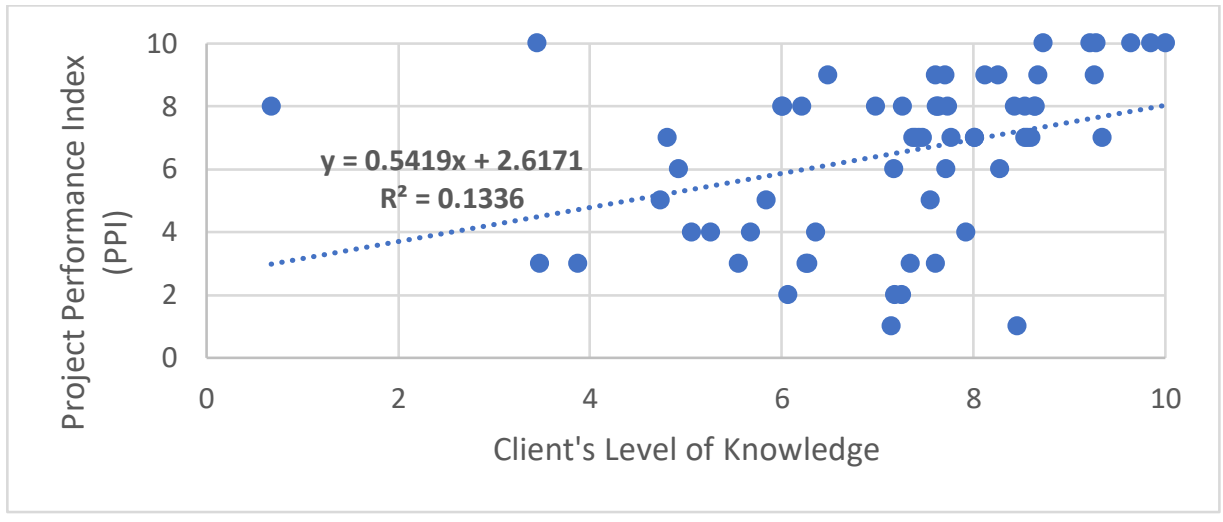

Insert: Figure 3: Relationship between level of Client's knowledge and PPI in Traditional procurement systems

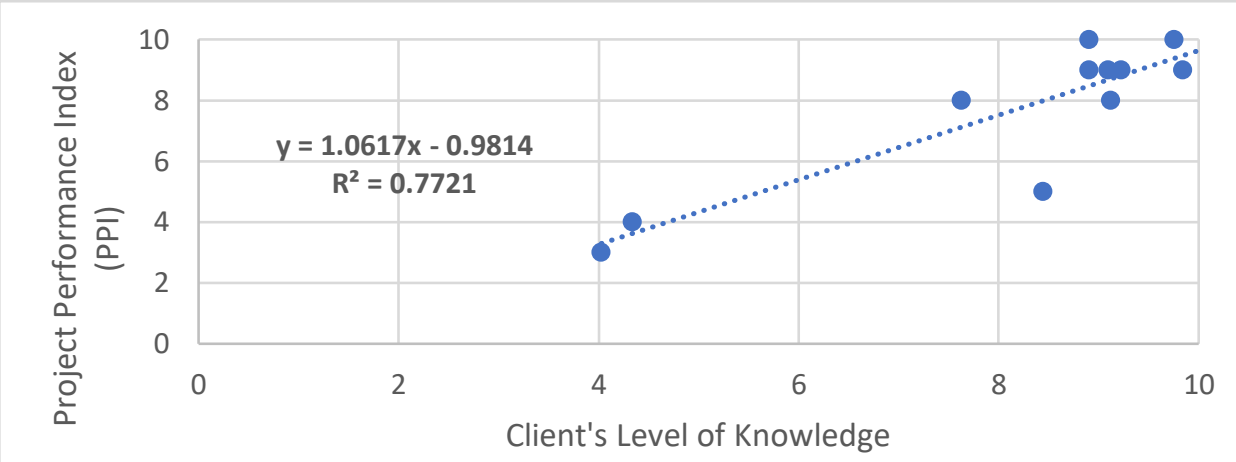

Figure 4: Relationship between level of Client's knowledge and PPI in Integrated procurement systems 


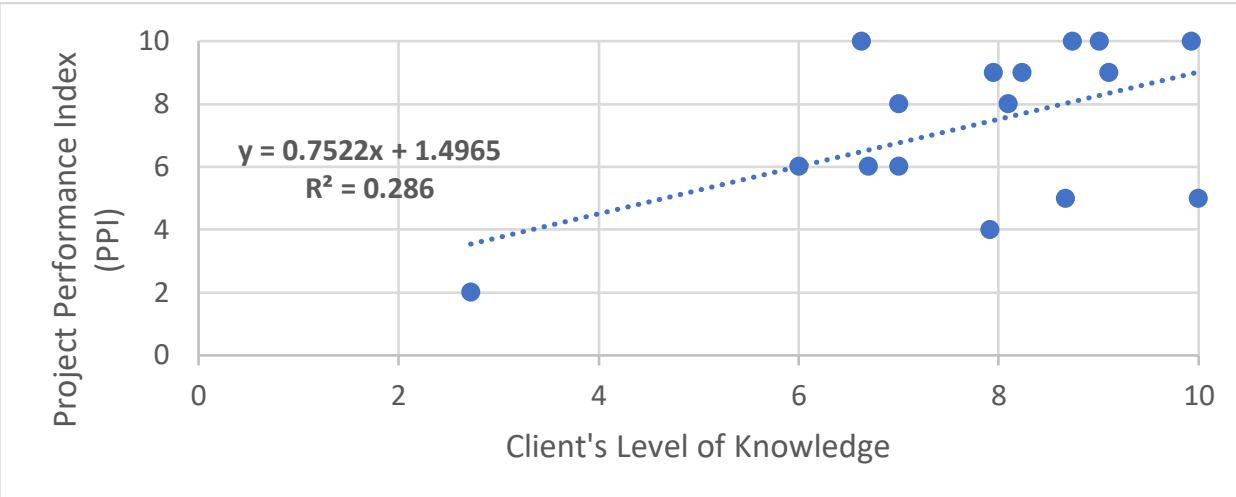

Figure 5: Relationship between level of Client's knowledge and PPI in Management oriented procurement systems

The relationship between clients' knowledge and project performance is merely indicative of correlation and not causation. Although, the regression analysis results presented in Figures 3, 4 and 5 gives an idea of how much a change in project performance can be explained by clients' knowledge when all other factors are constant. The $77 \%$ of changes in project performance in integrated procurement systems including design and build due to change in client level of knowledge is insightful because client experience/expertise of construction is not a prerequisite for the procurement methods as authors such as Mason (2016) show. While the current study did not examine the subject based on the types of clients (e.g. private and public), the differences therein because of the level of accountability, experience and interest may offer further insight into the discourse as Umeokafor (2018) indicates. Nevertheless, the current study draws the attention of stakeholders in construction and engineering projects to the potential threat and/or opportunities that the level of client knowledge of procurement can present to the performance of the project.

Findings of this study are aligned to previous studies by Grobler and Pretorius (2002) and Mbanjwa and Basson (2003), who found that Southern Africa utilizes traditional procurement more often than other procurement systems, followed by management oriented and integrated systems. Traditional procurement method is also the most commonly used outside South Africa (Constructing Excellence 2015; Mason 2016). It is also aligned with earlier studies that consider time, cost and quality as key project performance criteria (see Ng et al., 2012; Umeokafor 2018). In addition, the results of this study confirm the results of previous studies such as Windapo and Rotimi (2012) that there is a relationship between project success and factors such as client's level of knowledge and their ability to communicate their needs, which would influence the selection of an appropriate procurement method. There were no previous studies that considered whether the level of knowledge possessed by a client influences project performance, which are key findings of this study. 


\section{Conclusion, implications and recommendations}

This study examines the procurement system frequently used on construction projects in South Africa and whether the clients' knowledge of procurement systems is related to project performance. The study found that traditional procurement is the most frequently used procurement system on projects in South Africa and that the client's knowledge is significantly and positively related to project performance and project performance has a best fit with client's knowledge level within the integrated procurement system. Based on these findings, it can be concluded that procurement systems are selected inappropriately by clients in South Africa, despite the emergence of more efficient procurement systems. The clients' knowledge helps them in navigating the project procurement process. The more knowledge possessed by a client the higher the project performance in the integrated procurement system.

The practical implications of the research suggest the need for clients to seek ways to improve their understanding or increase their knowledge of procurement systems in construction. This can be through self-acquired knowledge, through attending industry organised events, sourcing industry materials on procurement. These can be good sources of acquiring information to improve the knowledge gap. Further, the strategic role of construction consultants/experts in advising and educating clients on procurement systems in the preconstruction stage is emphasised in this research, suggesting the need for them to exploit this position. By implication, clients can benefit from this by tapping from consultants/experts knowledge and expertise in procurement and construction in general. Other implications include policymakers' responsibilities in driving policies that will place responsibilities on clients to seek reasonable ways to improve their knowledge of procurement and construction in general. These policies must enable the enforcement of client obligation to seek reasonable ways to improve their knowledge of procurement and construction in general.

In relation to education, the findings of the study imply the need for relevant educational materials that target clients, their representatives and their advisors to emphasise and show them how the characteristics of the main procurements can influence project performance. This will enable clients make informed decisions that have considered the potentials and features of the procurement systems. The implication of all the above is that the housing and infrastructure needs of the society have higher chances of improvement if the adequate procurement method is selected when the client has a better knowledge of the procurement systems.

The study therefore recommends that knowledgeable clients should make more frequent use of the integrated procurement system, in order to increase the chances of successful project outcomes. Policymakers and professional bodies should consider ways of improving client knowledge of procurement by providing or ensuring that clients have adequate information in that regard. The research conducted is limited to projects in South Africa and therefore, caution should be taken when generalizing these results to other contexts. Also, examining whether the influences differ at the various stages of the project may offer valuable insight into the discourse hence further studies are recommended. Lastly, further research can seek to understand in detail the influence of client knowledge 
of procurement on project performance especially on projects procured through the integrated procurement routes such as Design and Build.

\section{Acknowledgement}

The authors would like to acknowledge with thanks, the assistance of the following people in conducting the survey and interviews: Tinotenda Jeketera, Mishara Naidoo and Yudish Sumputh.

\section{References}

Abudayyeh, O., Zidan, S. J., Yehia, S., \& Randolph, D. (2007). Hybrid prequalificationbased, innovative contracting model using AHP. Journal of management in engineering, Vol. 23 No.2, pp.88-96.

Alhazmi, T. and McCaffer, R. (2000). Project Procurement System Selection Model. Journal of Construction Engineering and Management, Vol. 126 No. 3, pp.176-184.

Alinaitwe, H.M. (2008), "An assessment of clients' performance in having an efficient building process in Uganda", Journal of Civil Engineering and Management, Vol.

14 No. 2, pp. 73-78.

Akinkunmi, G. A. O., Aghimien, D. O., and Awodele, O. A. (2018), 'Appraising the Use of Labour-Only Procurement System for Building Construction in Nigeria', Organisation, Technology and Management in Construction, Vol. 10 No.1, pp. 17191726.

Avella, J. R. (2016). Delphi panels: Research design, procedures, advantages, and challenges. International Journal of Doctoral Studies, vol.11, pp.305-321.

Borg, L. (2015) Procurement Contracts, Innovation and Productivity in the Construction Sector: Five Studies. Doctoral Thesis KTH Royal Institute of Technology. Available on https://www.diva-portal.org/smash/get/diva2:872950/FULLTEXT02 (Accessed: 25 May 2020)

Chartered Institute of Building (CIOB) (2016) Productivity in construction: Creating a framework for the industry to thrive, Available https://policy.ciob.org/wp-content/uploads/2016/05/CIOB-Productivity-report-2016v4_single.pdf (Accessed: 22 May 2020)

Chen, Y., Okudan, G. and Riley, D. (2010). Sustainable performance criteria for construction method selection in concrete buildings. Automation in Construction, Vol. 19 No.2, pp.235-244.

cidb, (2011). Construction quality in South Africa; A client perspective. Pretoria: cidb. cidb, (2014). The cidb Construction Industry Indicators: Summary Results. Construction Industry Indicators. Pretoria: cidb.

Chartered Institute Of Building (CIOB) (2010). Procurement in the construction industry 2010. Berkshire: The Chartered Institute of Building.

Chua, D. K. H., Kog, Y. C., \& Loh, P. K. (1999). Critical success factors for different project objectives. Journal of construction engineering and management, Vol.125, No.3, pp.142-150.

Constructing Excellence (2015) Procurement. Available at https://constructingexcellence.org.uk/wp-content/uploads/2015/03/procurement.pdf (Accessed: 23 May 2020)

Cooperative Research Centre, (2008). Building Procurement Methods. CRC Construction 
Innovation. Brisbane: Icon.Net Pty Ltd.

Coviello, N. E. and Jones, M. V. (2004), "Methodological issues in international entrepreneurship research", Journal of Business Venturing, Vol. 19, No. 4, pp. 485508.

Doloi, H. (2008). Application of AHP in improving construction productivity from a management perspective. Construction Management and Economics, 26(8), pp. 841-854.

Dulami, M.F., Ling, F.Y.Y., Bajracharya, A., (2003) Organizational Motivation and InterOrganizational Interaction in Construction Innovation in Singapore, Construction Management and Economics, Vol. 21 No3, pp. 307-318

Eriksson, P. and Westerberg, M. (2011), 'Effects of Cooperative Procurement Procedures on Construction Project Performance: A Conceptual Framework', International Journal of Project Management, Vol.29 No.2, pp. 197-208.

Grobler, K. and Pretorius, L. (2002). An Evaluation of Design-Build as a Procurement Method for Building and Civil Engineering Projects in South Africa. Journal of the South African Institution of Civil Engineering, Vol.44 No.1, pp.13-19.

Habibi, M.; Kermanshachi, S.; Rouhanizadeh, B. (2019) Identifying and Measuring Engineering, Procurement, and Construction (EPC) Key Performance Indicators and Management Strategies. Infrastructures, Vol.4 No.14, 1-19.

Hughes, W., Champion, R. and Mirduch, J. (2015) Construction Contracts: Law and Management, $5^{\text {th }}$ Edn. London: Routhledge

Kamara, J., Anumba, C. and Evbuomwan, N. (2002). Capturing client requirements in construction projects. London: Thomas Telford.

Kumaraswamy, M. and Dissanayaka, S. (1998). Linking procurement systems to project priorities. Building Research \& Information, Vol.26 No.4, pp.223-238.

Kumaraswamy, M. and Dissanayaka, S. (2001). Developing a decision support system for building project procurement. Building and Environment, Vol.36 No.3, pp.337349.

Ibbs, C. W., Kwak, Y. H., Ng, T., Odabasi A.M. (2003). Project delivery systems and project change: quantitative analysis. Journal of Construction Engineering and Management. Vol.129 No4,382-387.

Lam, E., Chan, A. and Chan, D. (2003). Why is Design-Build Commonly Used in the Public Sector? An Illustration from Hong Kong. AJCEB, Vol.3 No1, p.53.

Latham, M. (1994). Constructing the Construction team. The Latham Report: Final Report of the Government/Industry Review of Procurement and Contractual Arrangements in the UK Construction Industry. HMSO.

Mason, J. (2016) Construction Law: From Beginners to Practitioner. London: Routledge.

Mathonsi, M. and Thwala, W. (2009). Investigation of Factors That Influence the Selection of Procurement Systems of the South African Construction Industry. CIDB Paper 13.

Mathonsi, M. D, and Thwala, W. D (2012). Factors influencing the selection of procurement systems in the South African construction industry. African Journal of Business Management, Vol. 6 No.10. pp. 3583-3594.

Mbachu, J. and Nkado, R. (2006). Conceptual framework for assessment of client needs and satisfaction in the building development process. Construction Management and Economics, Vol. 24 No.1, pp.31-44.

Mbanjwa, S. and Basson, G. (2003). The Use and Effectiveness of Construction Management as a Building Procurement System in the South African Construction Industry. Master of Science (Project Management). University of Pretoria. 
Mfongeh, N. (2010). The constraints of using design and build for the procurement of construction projects in South Africa. Master's degree. University of the Witwatersrand.

Moghayedi, A., Windapo, A., 2018. Key performance criteria influencing the selection of construction methods used for the fabrication of building components in the middle east. Sustainable Constr. Build. Mater. http://dx. doi.org/10.5772/intechopen.81673.

Mosley, J.C. and Bubshait, A. A. (2019) Investigative study of project procurement methods and project performance indicators in Saudi Arabia. International Journal of Construction Management. DOI: 10.1080/15623599.2019.1588842

Ng, T., Luu, D. and Chen, S. (2002). Decision Criteria and Their Subjectivity in Construction Procurement Selection. AJCEB, Vol.2 No1, p.70.

Oladapo, A. (2011). Multi-criteria contractor selection: A practical application of analytic hierarchy process. Proceedings of the ICE - Management, Procurement and Law, 164(2), pp.79-88.

Pallant, J. (2010). PASW and SPSS survival manual. Maidenhead: Open University Press

Pomponi, F., Moghayedi, A., Alshawawreh, L., D’Amico, B., \& Windapo, A. (2019). Sustainability of post-disaster and post-conflict sheltering in Africa: What matters?. Sustainable Production and Consumption, Vol. 20, pp.140-150.

Ratnasabapathy, S. and Rameezdeen, R. (2010). A Decision Support System for the Selection of Best Procurement System in Construction. Built-Environment Sri Lanka, Vol.7 No.2, pp. 43-53.

Rwelamila, P. and Meyer, C. (1999). Appropriate or Default Project Procurement Systems? Cost Engineering, Vol.41 No.9, pp. 40-44.

Saaty TL (2001) Decision Making with Dependence and Feedback: The Analytical Network Process. RWS Publications, Pittsburgh, PA, USA.

Saaty, T. (1994). How to Make a Decision: The Analytic Hierarchy Process. Interfaces, Vol. 24( No.6, pp.19-43.

Saaty TL (2001) Decision Making with Dependence and Feedback: the Analytical Network Process. RWS Publications, Pittsburgh, PA, USA.

Santoso, D.S. and Gallage, P.G.M.P. (2019), Critical factors affecting the performance of large construction projects in developing countries: A case study of SriLanka, Journal of Engineering, Design and Technology, Vol. 18 No. (3), pp.531556.

Thwala, W. and Mathonsi, M. (2012). Selection of Procurement Systems in the South African Construction Industry: An Exploratory Study, Vol.12 No. 1, pp. 13-26 DOI: $10.4102 /$ ac.v12i1.127

Ugwu, O. and Haupt, T. (2007). Key performance indicators and assessment methods for infrastructure sustainability. A South African construction industry perspective. Building and Environment, Vol. 42 No.2, pp.665-680.

United Nations (2020) Goal 9: Build resilient infrastructure, promote sustainable industrialization and foster innovation. Available on https://www.un.org/sustainabledevelopment/infrastructure-industrialization/ (Accessed: 24 May 2020)

Umeokafor, N. 2017. An appraisal of the barriers to client involvement in health and safety in Nigeria's construction industry. Journal of Engineering, Design and Technology, Vol. 15 No.4, pp. 417-487.

Umeokafor (2018) An investigation into public and private client attitudes, commitment and impact on construction health and safety in Nigeria. Engineering, Construction 
and Architectural Management, Vol.29 No.6, 798-815

Vaidya, O. and Kumar, S. (2006). Analytic hierarchy process: An overview of applications. European Journal of Operational Research, Vol.169 No1, pp.1-29.

Warsame, A., Borg, L., and Lind, H. (2013) How Can Clients Improve the Quality of

Transport Infrastructure Projects? The Role of Knowledge Management and Incentives. The Scientific World Journal, pp. 1-8, http://dx.doi.org/10.1155/2013/709423

Windapo, A. and Rotimi, J. (2012). Determining project performance criteria and key procurement methods in Nigeria: Client's perspective. Joint CIB W070, W092 \& TG72 International Conference on Facilities Management, Procurement Systems and Public Private Partnership - Delivering Value to the Community. Emerald, pp.250 259. 